\title{
Effect of Sn Addition on Microstructure and Corrosion Behavior of As-Extruded Mg-5Zn-4Al Alloy
}

\author{
Jian Ding ${ }^{1}$, Xin Liu ${ }^{1}$, Yujiang Wang ${ }^{2}$, Wei Huang ${ }^{2}$, Bo Wang ${ }^{2, *}$, Shicheng Wei ${ }^{2, *}$, \\ Xingchuan Xia ${ }^{1}$, Yi Liang ${ }^{2}$, Xianhua Chen ${ }^{3}$, Fusheng Pan ${ }^{3}$ and Binshi $X u^{2}$ \\ 1 School of Material Science and Engineering, Hebei University of Technology, Tianjin 300130, China \\ 2 National Key Laboratory for Remanufacturing, Academy of Army Armored Forces, Beijing 100072, China \\ 3 College of Materials Science and Engineering, Chongqing University, Chongqing 400045, China \\ * Correspondence: wangbobo421@163.com (B.W.); wsc33333@163.com (S.W.); Tel.: +86-010-66718540 (B.W.); \\ +86-010-66719083 (S.W.)
}

Received: 4 June 2019; Accepted: 25 June 2019; Published: 27 June 2019

check for updates

\begin{abstract}
The effect of $\mathrm{Sn}$ addition on the microstructure and corrosion behavior of extruded $\mathrm{Mg}-5 \mathrm{Zn}-4 \mathrm{Al}-\mathrm{xSn}(0,0.5,1,2$, and $3 \mathrm{wt} \%)$ alloys was investigated by optical microscopy (OM), field emission scanning electron microscopy (FE-SEM), transmission electron microscopy (TEM), X-ray diffraction (XRD), X-ray photoelectron spectroscopy (XPS), electrochemical measurements, and immersion tests. Microstructural results showed that the average grain size decreased to some degree and the amount of precipitates increased with the increasing amount of $\mathrm{Sn}$. The extruded $\mathrm{Mg}-5 \mathrm{Zn}-4 \mathrm{Al}-\mathrm{xSn}$ alloy mainly consisted of $\alpha-\mathrm{Mg}, \mathrm{Mg}_{32}(\mathrm{Al}, \mathrm{Zn})_{49}$, and $\mathrm{Mg}_{2} \mathrm{Sn}$ phases as the content of Sn was above $1 \mathrm{wt} \%$. Electrochemical measurements indicated that the extruded $\mathrm{Mg}-5 \mathrm{Zn}-4 \mathrm{Al}-1 \mathrm{Sn}$ (ZAT541) alloy presented the best corrosion performances, with corrosion potential ( $\left.\mathrm{E}_{\mathrm{corr}}\right)$ and corrosion current density $\left(\mathrm{I}_{\text {corr }}\right)$ values of $-1.3309 \mathrm{~V}$ and $6.707 \times 10^{-6} \mathrm{~A} \cdot \mathrm{cm}^{-2}$, respectively. Furthermore, the corrosion mechanism of $\mathrm{Sn}$ is discussed in detail.
\end{abstract}

Keywords: Mg-5Zn-4Al; Sn; microstructure; corrosion property; anticorrosion mechanism

\section{Introduction}

Magnesium alloys have been widely used in the aerospace and automobile industries, electronics, and various other fields because of their light weight, high strength/weight ratios, good thermal conductivity, and excellent electromagnetic shielding characteristics [1-3]. However, commercial applications have been limited due to their poor corrosion resistance, especially in aggressive chloride ion environments $[4,5]$.

To improve their corrosion resistance, alloying [6-8], surface modification [9-12], heat treatment [13], and the plastic deformation process [14] have been applied. Among these methods, alloying is an effective way to improve anticorrosion properties. Thus, various elements, including $\mathrm{Al}, \mathrm{Zn}, \mathrm{Ca}, \mathrm{Sr}, \mathrm{RE}, \mathrm{Sn}$, and $\mathrm{Si}$, have been added to $\mathrm{Mg}$ alloys to change their anticorrosion properties. Among these, RE, Al, Zn, and Sn show great advantages in terms of anticorrosion properties. RE is an element that has the potential to improve the corrosion resistance of $\mathrm{Mg}$ alloys [15,16]. However, the exploitation and refinement of rare earths can cause serious damage to renewable energy, which limits the wide application of RE [17]. Al and Zn are most commonly used in $\mathrm{Mg}$ alloys due to their grain refinement and solid solution strengthening effect $[18,19]$. However, there is much more microgalvanic corrosion as the concentration of $\mathrm{Al}$ and $\mathrm{Zn}$ increases, leading to poor corrosion resistance. Further, $\mathrm{Sn}$ has been attracting more and more attention because of its grain refinement and reduction of the hydrogen evolution rate of $\mathrm{Mg}$ alloys [20,21]. Therefore, it is necessary to find one low-cost alloy system to improve the corrosion resistance performance of $\mathrm{Mg}$ alloys. 
In recent years, much more attention has been paid to $\mathrm{Mg}-\mathrm{Zn}-\mathrm{Al}-\mathrm{Sn}$ (ZAT) alloys due to their low cost, high strength, and excellent plasticity both at room and elevated temperatures. It has been proved that the tensile strength and elongation of ZAT alloys can reach $300 \mathrm{MPa}$ and 20\% [22,23], respectively, which is superior to traditional ZM5 or ZK60 and comparable to Mg-RE alloys [24]. Although several studies have been done on the mechanical properties of ZAT alloys [22,23,25-30], few researchers have focused their attention on their corrosion resistance [31-33]. Further, the corrosion mechanism and corrosion product types of ZAT alloys are not yet clearly understood. Therefore, it is necessary to study the effect of $\mathrm{Sn}$ on the corrosion resistance of $\mathrm{Mg}-\mathrm{Zn}-\mathrm{Al}$ alloys.

In the present work, the microstructure evolution and corrosion behavior of as-extruded $\mathrm{Mg}-5 \mathrm{Zn}-4 \mathrm{Al}-\mathrm{xSn}(0,0.5,1,2$, and $3 \mathrm{wt} \%)$ alloys were investigated systematically. The purpose was to explore the optimum $\mathrm{Sn}$ addition amount for the highest corrosion resistance of the $\mathrm{Mg}-5 \mathrm{Zn}-4 \mathrm{Al}$ system and to clarify the corrosion mechanism of Sn-containing $\mathrm{Mg}-\mathrm{Zn}-\mathrm{Al}$ alloys. The findings of this study will aid in the development of high-corrosion-resistance and low-cost Mg alloys.

\section{Experimental Procedures}

\subsection{Sample Preparation}

Mg ingot (99.95\%), Zn ingot (99.99\%), Al ingot (99.95\%), and Sn (99.99\%) were used for the matrix to prepare the $\mathrm{Mg}-5 \mathrm{Zn}-4 \mathrm{Al}-\mathrm{xSn}$ alloy. Prior to melting, the materials were placed in an electric resistance furnace at $720^{\circ} \mathrm{C}$ under the protection atmosphere of $\mathrm{CO}_{2}$ and $\mathrm{SF}_{6}$. Subsequently, the molten alloy was stirred for $10 \mathrm{~min}$ at $740{ }^{\circ} \mathrm{C}$ to remove slag inclusion and impurities, and the temperature was held for $20 \mathrm{~min}$ to homogenize the composition. The detailed preparation process was described previously [23,26]. The dimensions of the cast billet were $80 \mathrm{~mm}$ in diameter and $120 \mathrm{~mm}$ in length. The ingot composition was determined by inductively coupled plasma (ICP), as shown in Table 1 . The result was consistent with the nominal mass percentage in alloys. The extrusion temperature was $300{ }^{\circ} \mathrm{C}$, the extrusion ratio was $25: 1$, and the extrusion speed was $2 \mathrm{~mm} / \mathrm{s}$. It was necessary to preheat the ingots and extrude the molds before extrusion. Finally, the diameter of the extruded bar gained was $16 \mathrm{~mm}$.

Table 1. Composition analysis of cast Mg-5Zn-4Al-xSn (ZAT54x) alloys.

\begin{tabular}{cccccc}
\hline \multirow{2}{*}{ Alloy } & \multirow{2}{*}{ Nominal Composition } & \multicolumn{4}{c}{ Analyzed Composition (wt \%) } \\
\cline { 3 - 5 } & & Zn & Al & Sn & Mg \\
\hline ZAT540 & Mg-5Zn-4Al-0Sn & 5.02 & 3.52 & 0.00 & Bal \\
ZAT540.5 & Mg-5Zn-4Al-0.5Sn & 5.00 & 3.50 & 0.51 & Bal \\
ZAT541 & Mg-5Zn-4Al-1Sn & 5.01 & 3.56 & 1.03 & Bal \\
ZAT542 & Mg-5Zn-4Al-2Sn & 5.00 & 3.51 & 2.00 & Bal \\
ZAT543 & Mg-5Zn-4Al-3Sn & 5.02 & 3.54 & 3.01 & Bal \\
\hline
\end{tabular}

\subsection{Microstructural Characterization}

All of the metallographic samples were cut from the center of the ingots perpendicular to the extrusion direction (ED) to ensure comparability. Optical microscopy (OM) (SMZ800, Nikon, Tokyo, Japan), field emission scanning electron microscopy (FE-SEM) (Nava Nano FE-SEM450/650, Eindhoven, Holland, accelerating voltage of $20 \mathrm{kV}$ ) equipped with an X-Max 80 energy-dispersive X-ray spectrometer (EDS, Horiba, Tokyo, Japan), and transmission electron microscopy (TEM) (LI-BRA200, Oberkochen, Germany) were used for microstructure observation. Prior to imaging for OM and SEM observation, the test samples were ground to 1500 grit by SiC papers, mechanically polished using alcohol, and dried in cold air. Subsequently, the specimens were etched with a mixture of $5 \mathrm{~g}$ picric acid, $40 \mathrm{~mL}$ ethanol, $5 \mathrm{~mL}$ acetic acid, and $10 \mathrm{~mL}$ deionized water. Image-Pro-Plus software (IPP 6.0, Media Cybernetics, Washington, DC, USA) was used for average grain size measurement and at least five optical micrographs were counted. X-ray diffraction (XRD) (D/MAX-2500PC, Rigaku, Tokyo, 
Japan) was used to analyze the phase by using $\mathrm{Cu} \mathrm{k} \alpha$. The diffraction angle was set from $20^{\circ}$ to $80^{\circ}$ with a scanning rate of $2^{\circ} / \mathrm{min}$.

\subsection{Electrochemical and Immersion Tests}

The corrosion behavior of the extruded Mg-5Zn-4Al-xSn alloys was measured by immersion tests, potentiodynamic polarization, and electrochemical impedance spectroscopy (EIS). Electrochemical behavior measurements of all specimens were carried out on an electrochemical workstation (IM6ex, Zahner, Kronach, Germany) under $3.5 \mathrm{wt} \% \mathrm{NaCl}$ solution at room temperature. All samples were cylindrical with a diameter of $16 \mathrm{~mm}$ and a height of $10 \mathrm{~mm}$. The effective area was about $2.01 \mathrm{~cm}^{2}$ $(\Phi 16 \mathrm{~mm})$. The classical three-electrode cell (the measured sample was the working electrode, a platinum plate was the auxiliary electrode, and the reference electrode was a $\mathrm{Ag} / \mathrm{AgCl}$ saturated calomel electrode) was adopted for the electrochemical test. Before the test, specimens were immersed into $3.5 \mathrm{wt} \% \mathrm{NaCl}$ solution for $300 \mathrm{~s}$ to obtain a stable open-circuit potential. Potentiodynamic polarization tests were carried out from -0.3 to $+0.6 \mathrm{~V}$ versus open-circuit potential with a scanning rate of $1 \mathrm{mV} / \mathrm{s}$. The polarization curves were fitted using CView-2 (Scribner, Southern Pines, NC, USA). EIS measurements of the as-prepared alloys were performed from $10^{-2}$ to $10^{5} \mathrm{~Hz}$ with $10 \mathrm{mV}$ sinusoidal perturbation amplitude and the results were fitted by Zview 2.0 software (Scribner). All experiments were performed more than three times to ensure repeatability and consistency.

\subsection{Corrosion Morphology and Products}

In order to describe the evolution of corrosion behavior and the origin of pitting corrosion more clearly, immersion tests were carried out. The polished specimens were immersed in electrolytes from $10 \mathrm{~min}$ to $1 \mathrm{~h}$, then washed with deionized water and cleaned with alcohol immediately. To investigate the initiation and propagation of corrosion, the surface corrosion morphology was recorded by the abovementioned SEM equipped with EDS. Microscopic corrosion products were examined by X-ray photoelectron spectroscopy (XPS) (Thermo Fisher Scientific, Waltham, MA, USA) after immersion in $3.5 \mathrm{wt} \% \mathrm{NaCl}$ solution for $48 \mathrm{~h}$.

\section{Results and Discussion}

\subsection{Microstructure}

Figure 1 illustrates the microstructure of extruded Mg-5Zn-4Al-xSn (ZAT54x) alloys with different $\mathrm{Sn}$ addition amounts. The average grain size decreased as the $\mathrm{Sn}$ content increased to $2 \mathrm{wt} \%$, and the average grain size increased as the content reached $3 \mathrm{wt} \%$. Statistical results showed that the average grain sizes of ZAT540, ZAT540.5, ZAT541, ZAT542, and ZAT543 alloys were 5.06 $\pm 2.31,4.1 \pm 1.20$, $3.5 \pm 1.63,3.31 \pm 1.58$, and $4.22 \pm 2.05 \mu \mathrm{m}$, respectively. This means that $S n$ can be used as a grain refiner for Mg alloys [28]. Obviously, the grain size of the ZAT54x alloys was extremely inhomogeneous and was mainly distributed in the range of $0.9-20 \mu \mathrm{m}$ due to the incompletely dynamic recrystallization during the extrusion process.

XRD results (Figure 2) showed that only $\alpha-\mathrm{Mg}$ and $\mathrm{Mg}_{32}(\mathrm{Al}, \mathrm{Zn})_{49}$ phases appeared where the $\mathrm{Sn}$ content was less than $2 \mathrm{wt} \%$, while for the alloys with Sn contents of $2 \mathrm{wt} \%$ (ZAT542) and $3 \mathrm{wt} \%$ (ZAT543), $\mathrm{Mg}_{2} \mathrm{Sn}$ diffraction peaks appeared and the diffraction peak intensities were enhanced as the $\mathrm{Sn}$ content increased. Formation of the $\mathrm{Mg}_{2} \mathrm{Sn}$ phase was primarily due to the higher electronegativity differences between Mg-Sn (0.65) than that of Sn-Al (0.35) and Sn-Zn (0.31) [34]. 


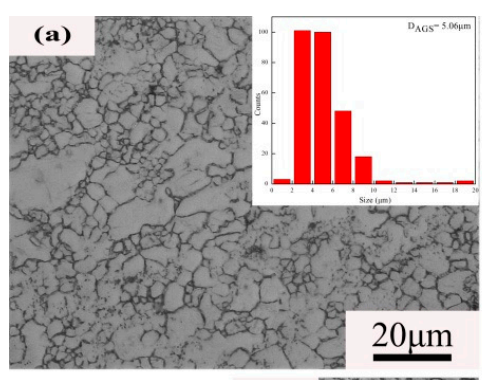

(d)

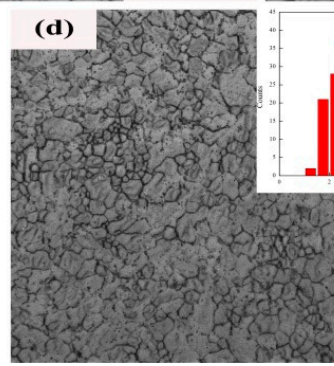

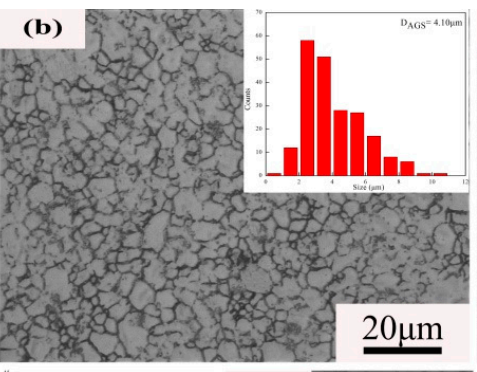

(e)

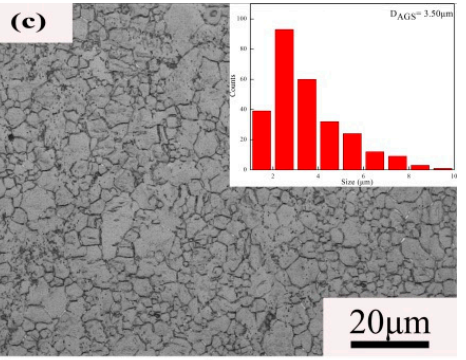

$\underline{20 \mu \mathrm{m}}$

Figure 1. Optical microscopy (OM) of extruded Mg-5Zn-4Al-xSn alloys: (a) ZAT540, (b) ZAT540.5, (c) ZAT541, (d) ZAT542, and (e) ZAT543.

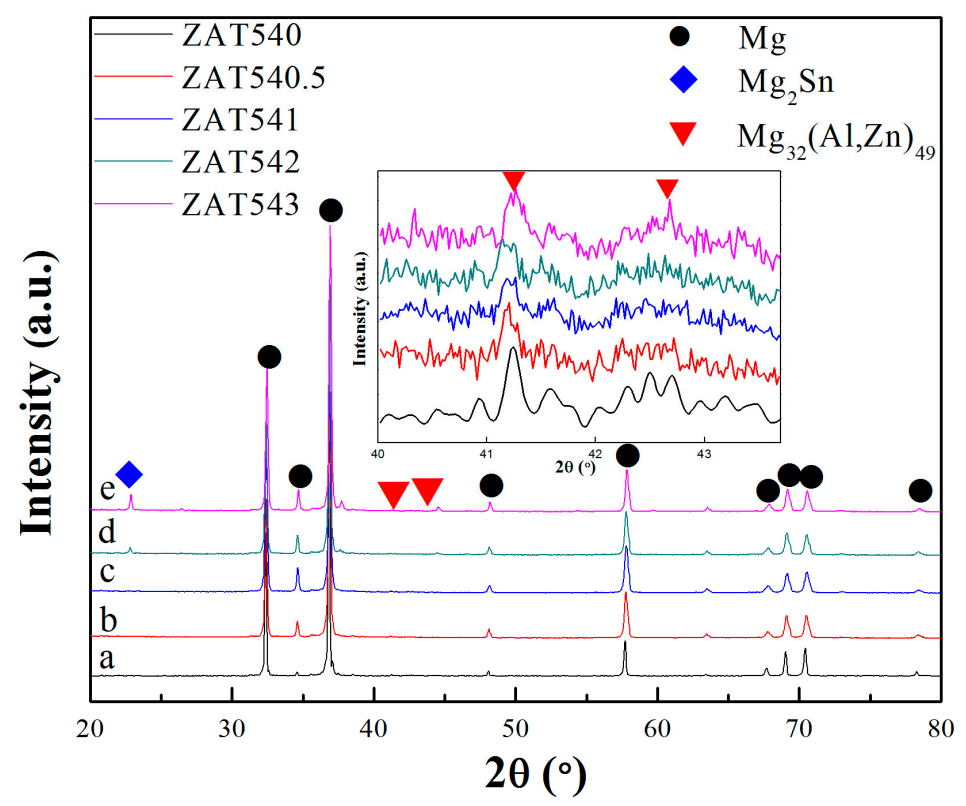

Figure 2. X-ray diffraction (XRD) patterns of extruded $\mathrm{Mg}-5 \mathrm{Zn}-4 \mathrm{Al}-\mathrm{xSn}$ alloys: (a) ZAT540, (b) ZAT540.5, (c) ZAT541, (d) ZAT542, and (e) ZAT543.

Figure 3 shows the microstructure evolution of ZAT54x alloys. A large number of precipitates were distributed in the grain boundaries and a small number of second phases in grain interiors. Meanwhile, the number of precipitated phases increased gradually as the amount of Sn increased. One interesting thing is that the grains near the precipitations were smaller compared with those of around the nonprecipitations (marked with red dotted lines), which implies that uniform recrystallization was formed. The reason was that the deformation zone near the hard particles became the preferred nucleation point for recrystallization due to the high dislocation density and large directional gradient during extrusion [35]. 


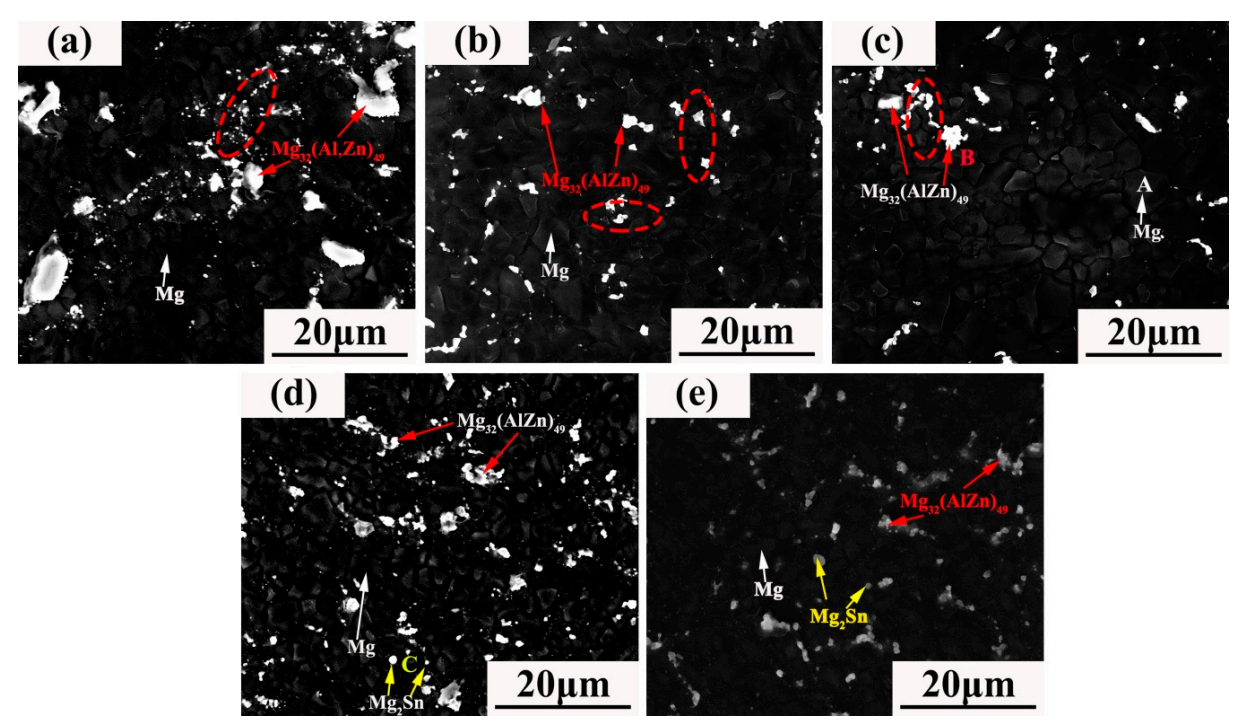

Figure 3. SEM images of extruded Mg-5Zn-4Al-xSn alloys: (a) ZAT540, (b) ZAT540.5, (c) ZAT541, (d) ZAT542, and (e) ZAT543.

In terms of SEM images, there were two different kinds of morphologies: bright flake-like of larger size (marked as B) and bright globular-shaped particles (marked as C). According to the EDS results shown in Table 2, B is rich in $\mathrm{Mg}, \mathrm{Zn}$, and $\mathrm{Al}$. Combined with XRD, B was deduced as being the $\mathrm{Mg}_{32}(\mathrm{Al}, \mathrm{Zn})_{49}$ phase. C particles were determined by EDS to contain about 73.90 at. $\% \mathrm{Mg}$ and 26.10 at. $\% \mathrm{Sn}$, and they may be the $\mathrm{Mg}_{2} \mathrm{Sn}$ phase.

Table 2. Energy-dispersive X-ray spectroscopy (EDS) detection of extruded ZAT541 and ZAT542 alloys.

\begin{tabular}{ccccc}
\hline \multirow{2}{*}{ Position } & \multicolumn{4}{c}{ Composition (at. \%) } \\
\cline { 2 - 5 } & $\mathbf{M g}$ & $\mathbf{Z n}$ & Al & Sn \\
\hline A & 90.88 & 05.30 & 03.82 & 0 \\
B & 62.55 & 19.17 & 18.28 & 0 \\
C & 73.90 & 0 & 0 & 26.10 \\
\hline
\end{tabular}

To clarify the composition of the precipitations in the extruded ZAT54x alloys, TEM detections on the ZAT541 alloy were carried out (Figure 4). There were much more secondary precipitates, large numbers of light-gray precipitations (marked as A), and a few black spherical particles (of finer size of about 10-50 nm in the grain boundary, marked as B) homogeneously in matrix. Moreover, it can be seen in Figure 4a that high-density dislocations were distributed at the grain boundary (red rectangle); further analysis is shown in Figure $4 \mathrm{~b}-\mathrm{f}$. Figure $4 \mathrm{~b}$ shows the selected area electron diffraction (SAED) of the matrix with a hexagonal close-packed structure (HCP). Figure 4c,d display the high-resolution episcopic microscopy (HREM) image and fast Fourier transform (FFT) pattern of A. According to our analysis, A can be identified as the $\mathrm{Mg}_{32}(\mathrm{Al}, \mathrm{Zn})_{49}$ phase with the space group Im3(204). This was consistent with the results from SEM and XRD. A typical spherical B particle is shown in Figure 4e. The SAED pattern of $B$ was confirmed by $<011>$ zone axes of $\mathrm{Mg}_{2} \mathrm{Sn}(\mathrm{a}=0.68 \mathrm{~nm})$ with a face-centered cubic (FCC) structure, as shown in Figure $4 \mathrm{f}$. The $\mathrm{Mg}_{2} \mathrm{Sn}$ phase could not be detected by SEM and XRD of the ZAT541 alloy because of its smaller dimension and quantity. Further, the $\mathrm{Mg}_{2} \mathrm{Sn}$ phase has the orientation relationship with the matrix wherein [2 -1 -1 0] Mg // [0 1 1] $\mathrm{Mg}_{2} \mathrm{Sn},\left(\begin{array}{lll}0 & 0 & 0\end{array}\right) \mathrm{Mg} / /$ (1 -1 1) $\mathrm{Mg}_{2} \mathrm{Sn}[28]$. 

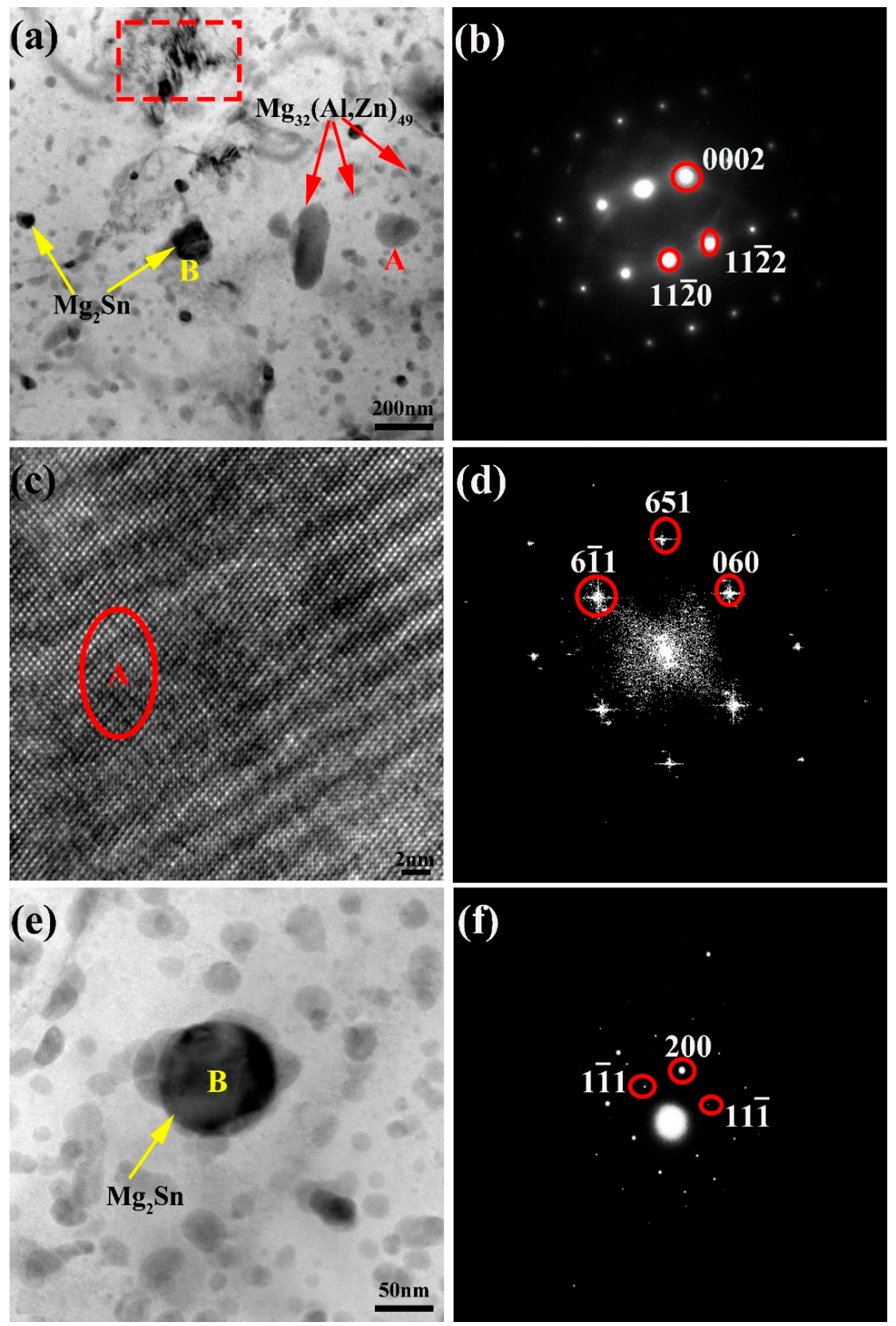

Figure 4. (a) Transmission electron microscopy (TEM) images of extruded ZAT541 alloy. (b) The selected area electron diffraction (SAED) of matrix. (c) High-resolution episcopic microscopy (HREM) image of precipitation A. (d) Fast Fourier transform (FFT) pattern obtained from A. (e) The high-magnification TEM morphology of a B particle. (f) The SAED of B.

From the microstructure analysis, the grain size decreased as the content of Sn increased (Figure 1; Figure 3). The reasons were that hot extrusion can cause lattice deformation and increase the density of dislocations and vacancies, causing an increase of storage strain energy [36]. High-density dislocations during extrusion are shown in Figure 4a. Strain energy can be used as a driving force for grain nucleation and growth during recrystallization. Further, finer $\mathrm{Mg}_{2} \mathrm{Sn}$ phases distributed at grain boundaries (Figure 4a) can act as nucleation particles to promote dynamic recrystallization by the particle-stimulated nucleation (PSN) mechanism [37]. Furthermore, the fine precipitates at the grain boundary can also inhibit grain growth by the boundary pinning effect [29]. When the Sn content was $3 \mathrm{wt} \%$, coarse $\mathrm{Mg}_{2} \mathrm{Sn}$ and $\mathrm{Mg}_{32}(\mathrm{Al}, \mathrm{Zn})_{49}$ precipitates formed in matrix, resulting in larger grain sizes due to grain the boundary pinning effect being reduced. Remarkably, the distribution of grain sizes 
during extrusion was extremely uneven (Figure 1). This was because the large number of precipitations increased the dislocation density and changed the uniformity of slip, leading to incomplete dynamic recrystallization during extrusion [30].

\subsection{Potentiodynamic Polarization Test}

The typical potentiondynamic polarization curves of the as-extruded alloys were tested in $3.5 \mathrm{wt} \%$ $\mathrm{NaCl}$ solution at room temperature, as displayed in Figure 5. There was the same trend in polarization curves with different $\mathrm{Sn}$ contents. The cathode was controlled by the reaction of hydrogen evolution and the anode dissolved by matrix as the applied anodic potential increased. This showed that the corrosion potential first increased and then decreased as the Sn content increased. When the Sn content was $1 \mathrm{wt} \%$, the corrosion potential of the polarization curve was the most positive. As it is clear, the corrosion potential of the extruded ZAT541 alloy shifted about $200 \mathrm{mV}$ to the positive direction compared with the ZAT543 and ZAT540 alloys. In addition, the anode current branches of the polarization curve moved to a relatively low value in the ZAT541 alloy, which indicates the reduction of the anodic dissolution rate and the corrosion protection of the alloy.

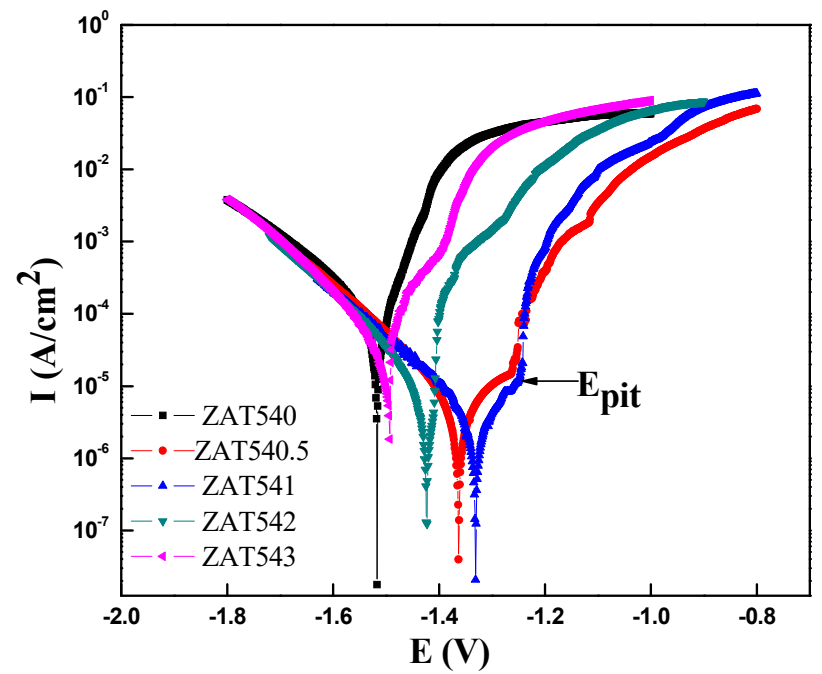

Figure 5. Polarization curves of extruded ZAT54x alloys in $3.5 \mathrm{wt} . \% \mathrm{NaCl}$ solution at room temperature.

There was obvious passivation behavior in the extruded ZAT54x alloys due to the formation of an oxide film on the alloys' surface. However, the anticorrosion properties of oxide film are undesirable because the anodic current densities rise slowly with the increasing anodic potential below the breakdown potential ( $\mathrm{E}_{\mathrm{pit}}$ as marked on the curves) due to the porous structure of oxide films [38].

The potentiodynamic polarization curves were analyzed by the cathodic Tafel extrapolation technique due to the negative difference effect (NDE) in the anodic branch for Mg alloys $[39,40]$. The fitting parameters of polarization, including corrosion potential $\left(\mathrm{E}_{\mathrm{corr}}\right)$, corrosion current density $\left(\mathrm{I}_{\mathrm{corr}}\right)$, and cathodic Tafel slope $B_{c}$, are given in the Table 3. The $\mathrm{E}_{\text {corr }}$ values of the ZAT540, ZAT540.5, ZAT541, ZAT542, and ZAT543 alloys were $-1.5173,-1.3628,-1.3309,-1.4235$, and $-1.4941 \mathrm{~V}$, respectively. Their

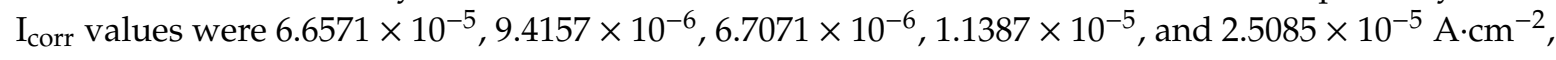
respectively. From the above results, the ZAT541 alloy showed excellent corrosion resistance. The reason was that solutionized Sn can inhibit the hydrogen evolution reaction at the cathodic branch of polarization curves due to the high hydrogen overpotential as the content of Sn was less than $2 \mathrm{wt} \%$, resulting in an increase in the corrosion resistance of the alloy [41]. Further, many more $\mathrm{Mg}_{2} \mathrm{Sn}$ precipitates were distributed in the grain boundary, which increased the probability of pitting and the corrosion propagation rate, accelerating the dissolution of the matrix. 
Table 3. Potentiodynamic polarization test results of extruded $\mathrm{Mg}-5 \mathrm{Zn}-4 \mathrm{Al}-\mathrm{xSn}$ alloys in $3.5 \mathrm{wt} \%$ $\mathrm{NaCl}$ solution at room temperature.

\begin{tabular}{cccc}
\hline Sample & $\mathbf{E}_{\text {corr }}(\mathbf{V})$ & $\mathbf{I}_{\text {corr }}\left(\mathbf{A} \cdot \mathbf{c m}^{-2}\right)$ & $\left.\mathbf{B}_{\mathbf{c}} \mathbf{( m V / d e c}\right)$ \\
\hline ZAT540 & -1.5173 & $6.6571 \times 10^{-5}$ & 130 \\
ZAT540.5 & -1.3628 & $9.4157 \times 10^{-6}$ & 172 \\
ZAT541 & -1.3309 & $6.7071 \times 10^{-6}$ & 203 \\
ZAT542 & -1.4235 & $1.1387 \times 10^{-5}$ & 139 \\
ZAT543 & -1.4941 & $2.5085 \times 10^{-5}$ & 126 \\
\hline
\end{tabular}

\subsection{Electrochemical Impedance Spectroscopy}

EIS results of all the samples are shown in Figure 6. As shown in Figure 6a, the Nyquist plots of the alloys consisted of a bigger semicircular loop at high frequencies, which we attributed to capacitance characteristics, and a semicircular loop at lower frequencies caused by the inductance of the alloys. Normally, the diameter of the capacitor plays an important role in evaluating the anticorrosion properties of alloys [42]. In the case of these specimens, the larger diameter, the better corrosion resistance of the alloy. Therefore, the extruded ZAT541 alloy showed the best anticorrosion properties. Figure $6 \mathrm{~b}$ displays the Bode phase plots versus frequency exposed in $3.5 \mathrm{wt} \% \mathrm{NaCl}$ solution. All alloys displayed two time constants, including a crest at high frequency and a wave trough at low frequency. It was a one-to-one match between the high-frequency capacitor loop and low-frequency inductance loop in the Nyquist plots. The deviation of the phase angle from $90^{\circ}$ showed a facile relative charge transfer during corrosion [43]. It can be seen that the extruded ZAT541 alloy with a higher phase angle $\left(-72.4^{\circ}\right)$ at high frequency resulted in better corrosion resistance. Figure 6c shows the Bode impedance plots of the specimens. The anticorrosion ability of alloys is usually evaluated by the magnitude of impedance modulus at low frequencies $\left(|Z|_{0.01 \mathrm{HZ}}\right)$. The impedance modulus of ZAT540, ZAT540.5, ZAT541, ZAT542, and ZAT543 alloys was 205, 327, 419, 290, and $154 \Omega \mathrm{cm}^{2}$, respectively. This implies that the ZAT541 alloy exhibited the strongest anticorrosion capability. All EIS results coincided with the polarization curve analyses.

From the above results, the equivalent electrical circuits were obtained by Zview 2.0 software. Figure 7 illustrates the equivalent circuit model, and fitting parameter data are shown in Table $4 . R_{s}$ indicates the electrolyte solution resistance between the working and reference electrodes. $C P E_{\mathrm{dl}}$ represents a constant phase element to compensate for the nonhomogeneity of the capacitor system, which is related to the electric double layer between the dielectric solution and the $\alpha$-Mg matrix at the interface. $R_{c t}$ is the charge transfer resistance. $L$ and $R_{L}$ stand for inductance and inductance resistance, respectively. The appearance of $\mathrm{L}$ means pitting corrosion of the alloy surface.

From the fitting data, $R_{c t}$ was $317.5,647.2,681.6,635.4$, and $345.6 \Omega \mathrm{cm}^{2}$, respectively. The $R_{c t}$ was the largest with the addition of $1 \mathrm{wt} \% \mathrm{Sn}$, reflecting the minimum dissolution rate of the substrate. However, excessive $\mathrm{Sn}$ addition caused the corrosion resistance to decrease. Based on impedance spectra and equivalent circuit fitting, the corrosion kinetics of the extruded ZAT54 $x$ alloys is described below. The interface between alloy surfaces and $\mathrm{NaCl}$ solution was formed the $\mathrm{CPE}$, and there was a charge transfer between two electrodes as the alloys were immersed in the $\mathrm{NaCl}$ solution. Microgalvanic corrosion occurred firstly on the matrix adjoined to the second phases due to the difference of potential. Because of the precipitates $\left(\mathrm{Mg}_{32}(\mathrm{Al}, \mathrm{Zn})_{49}\right.$ and $\left.\mathrm{Mg}_{2} \mathrm{Sn}\right)$ with high surface energy and activity, it could accelerate the corrosion rate and corrosion reactivity of the matrix. With the dissolution of the matrix, passivation formed on the surface of the alloys resulted in the formation of a corrosion product layer (Figure 5). However, it was loose and porous and could not protect the matrix effectively. Therefore, $\mathrm{Cl}^{-}$permeated the matrix through the protective film, leading to pitting corrosion. 

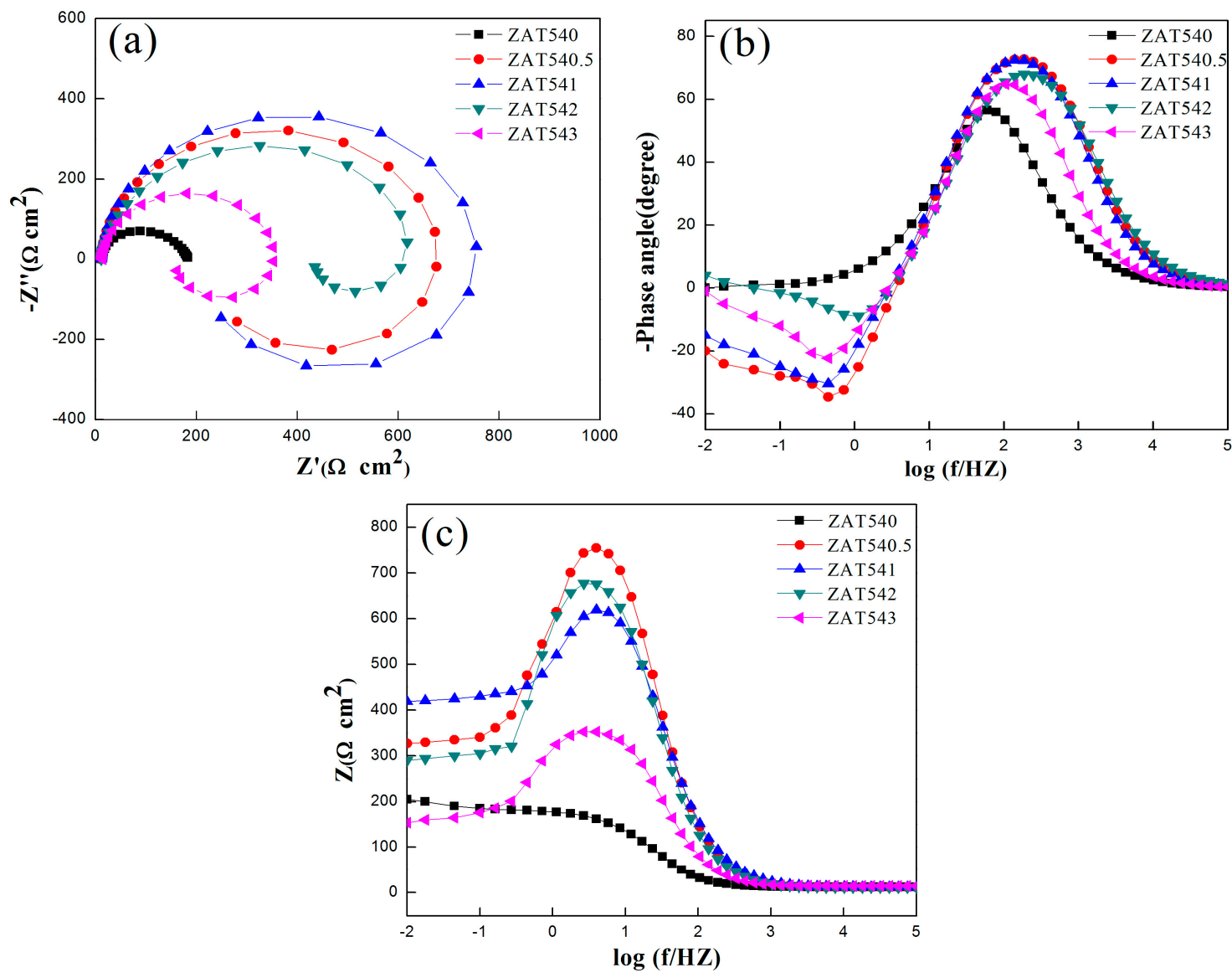

Figure 6. (a) Nyquist plots of ZAT54x alloys. (b) Bode plots of phase angle vs frequency for ZAT54x alloys. (c) Bode plots of impedance vs frequency for ZAT54x alloys.

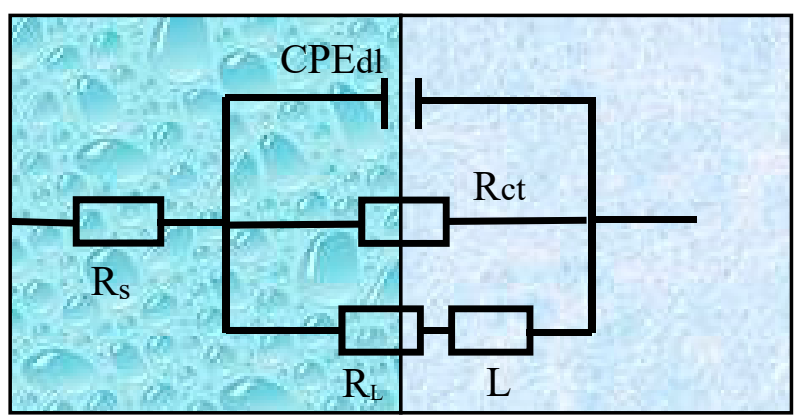

Figure 7. Equivalent circuit of electrochemical impedance spectroscopy (EIS) for extruded ZAT54x alloys.

Table 4. EIS fitting results of extruded $\mathrm{Mg}-5 \mathrm{Zn}-4 \mathrm{Al}-\mathrm{xSn}$ alloys.

\begin{tabular}{|c|c|c|c|c|c|c|}
\hline \multirow{2}{*}{ Alloys } & \multirow{2}{*}{$\begin{array}{c}\text { Rs } \\
\left(\Omega \mathrm{cm}^{2}\right)\end{array}$} & \multicolumn{2}{|c|}{$\mathrm{CPE}_{\mathrm{dl}}$} & \multirow{2}{*}{$\begin{array}{c}R_{\mathrm{ct}} \\
\left(\Omega \mathrm{cm}^{2}\right)\end{array}$} & \multirow{2}{*}{$\begin{array}{c}\mathrm{L} \\
\left(\mathrm{H} \mathrm{cm}^{-2}\right)\end{array}$} & \multirow{2}{*}{$\begin{array}{c}R_{\mathrm{L}} \\
\left(\Omega \mathrm{cm}^{2}\right)\end{array}$} \\
\hline & & $Q\left(S^{n} \Omega^{-1} \mathrm{~cm}^{-2}\right)$ & $\mathbf{n}$ & & & \\
\hline ZAT540 & 11.53 & $1.481 \times 10^{-5}$ & 0.9417 & 317.5 & 153.7 & 183.0 \\
\hline ZAT541 & 11.22 & $1.505 \times 10^{-5}$ & 0.9653 & 681.6 & 217.9 & 299.7 \\
\hline ZAT542 & 11.71 & $1.64 \times 10^{-5}$ & 0.9195 & 635.4 & 172.4 & 215.4 \\
\hline
\end{tabular}




\subsection{Corrosion Behavior}

The microstructure of the extruded ZAT543 alloy was immersed in $3.5 \mathrm{wt} \% \mathrm{NaCl}$ solution for $10 \mathrm{~min}$, as shown in Figure 8. The evolution and origination of pitting corrosion in the ZAT543 alloy was easier due to the large number of precipitations. Figure 8a shows the alloy pitting characteristics at low magnification. It can be observed that white corrosion products were adjacent to $\mathrm{Mg}_{2} \mathrm{Sn}$ metallic compounds (marked as region A), which appeared to fall off and cause corrosion phenomenon around the matrix severely, while the matrix around the $\mathrm{Mg}_{32}(\mathrm{Al}, \mathrm{Zn})_{49}$ phase was uncorroded. Figure $8 \mathrm{~b}$ is the high-magnification pitting morphology of region A, and corresponding EDS are inserted in the image. It shows that pitting corrosion preferentially occurred at $\mathrm{Mg}_{2} \mathrm{Sn}$ precipitation due to the noble potential, and $\mathrm{Mg}_{32}(\mathrm{Al}, \mathrm{Zn})_{49}$ can be a corrosion-resistant phase.
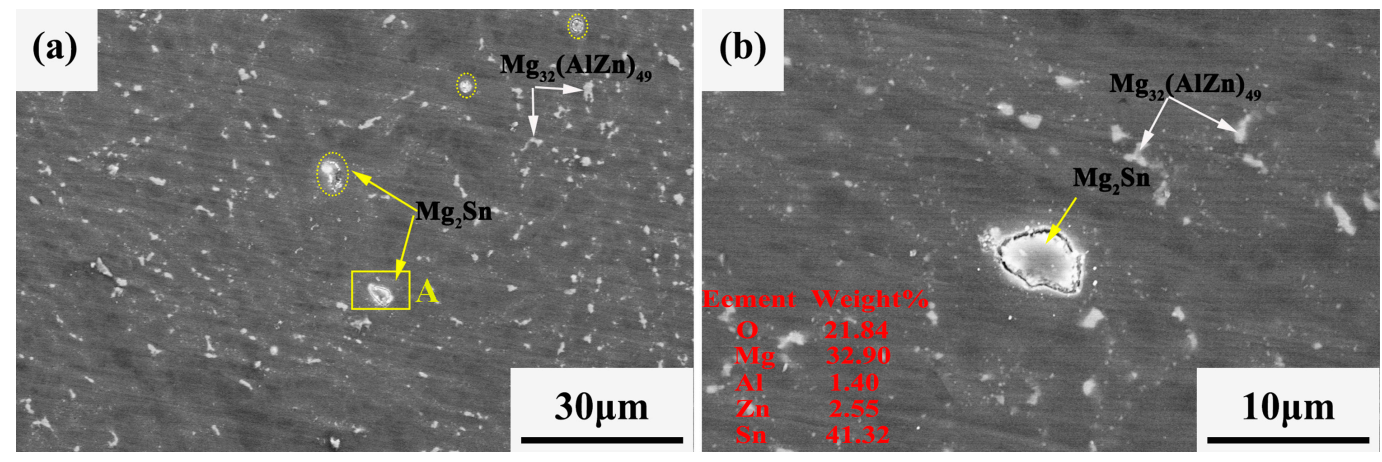

Figure 8. (a) Initiation corrosion sites of ZAT543 alloy immersed in $3.5 \mathrm{wt} \% \mathrm{NaCl}$ for $10 \mathrm{~min}$; (b) high-magnification morphology of region A.

The morphology of the extruded ZAT543 alloy was immersed in $3.5 \mathrm{wt} \% \mathrm{NaCl}$ solution for $1 \mathrm{~h}$, as shown in Figure 9. Figure 9a shows that typical filiform corrosion and cracks appeared in the contact between the matrix and the corrosion products on the surface of ZAT543. A lamellar gray corrosion product layer adhered to the surface of the alloys with the white needle-like globular product on the top layers (Figure 9b). The reason for the cracks in the corrosion product layer is as follows. Firstly, pitting corrosion occurred at different locations due to various precipitates existing in the alloys. Corrosion products that formed at different locations collided to crack when they touched each other due to the different growth rates. Then, $\mathrm{MgO}$ of the cubic crystal systems transformed into $\mathrm{Mg}(\mathrm{OH})_{2}$ of the hexagonal crystal system, leading to the volume of products expanding twice as much as before. Lastly, a large amount of the $\mathrm{Cl}^{-}$loose corrosion product layer resulted in peeling as $\mathrm{Cl}^{-}$permeated into the matrix through porous film layers. As shown in Figure 9c, corrosion products of the alloy surface determined by EDS contained about 32.76 at. \% Mg, 2.95 at. \% Al, and 64.29 at. \% O. There was no $\mathrm{H}$ because EDS could not detect it. This means that the needle-like white corrosion products were $\mathrm{Mg}(\mathrm{OH})_{2}$.
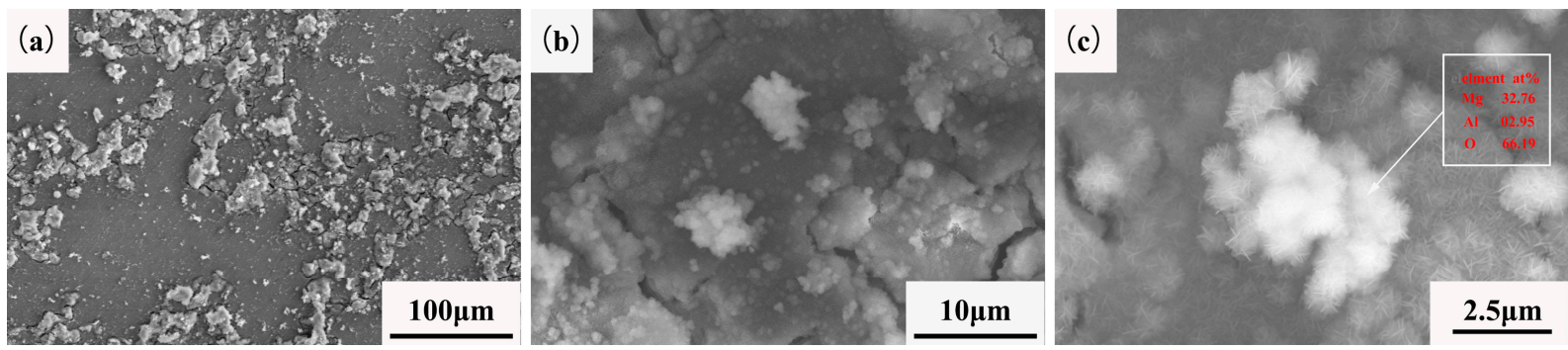

Figure 9. (a) Corrosion morphology of ZAT543 alloy immersed in $3.5 \mathrm{wt} \% \mathrm{NaCl}$ for $1 \mathrm{~h}$; (b) high-magnification corrosion morphology; (c) corrosion products of ZAT543 alloy. 


\subsection{Corrosion Products Analysis}

The corrosion products of the extruded ZAT543 alloy immersed in $3.5 \mathrm{wt} \% \mathrm{NaCl}$ for $48 \mathrm{~h}$ were detected by XPS, and the result is shown in Figure 10. There was $\mathrm{C}, \mathrm{O}, \mathrm{Cl}, \mathrm{Mg}, \mathrm{Zn}, \mathrm{Al}$, and $\mathrm{Sn}$ in the corrosion products of the ZAT543 alloy. As for C 1s, the binding energy was approximately 284.5 and $289.5 \mathrm{eV}$, corresponding to adventitious $\mathrm{C}$ and $\mathrm{CO}_{3}{ }^{2-}$. As for O 1s, there were two peaks corresponding to $\mathrm{OH}^{-}$and $\mathrm{O}^{2-}$, which proved the existence of hydroxide and oxide. As for $\mathrm{Cl} 2 \mathrm{p}$, the peak at $198.5 \mathrm{eV}$ originated from $\mathrm{Cl}^{-} \cdot \mathrm{nH}_{2} \mathrm{O}$, which means that there were basic chloridion compounds in the corrosion products. In the case of the $\mathrm{Mg} 1 \mathrm{~s}$ spectrum, the peaks at approximately $102.7,1303.8$, and $1304.8 \mathrm{eV}$ originated from $\mathrm{Mg}(\mathrm{OH})_{2}, \mathrm{MgCO}_{3}$, and $\mathrm{MgCl}_{2} \cdot 6 \mathrm{H}_{2} \mathrm{O}$, respectively. For $\mathrm{Zn} 2 \mathrm{p}$, there were two peaks corresponding to $\mathrm{Zn} 2 \mathrm{p} 1 / 2$ and $\mathrm{Zn} 2 \mathrm{p} 3 / 2$. This means that there was $\mathrm{ZnO}$ in the corrosion products. For the $\mathrm{Al} 2 \mathrm{p}$ spectrum, the binding energy was approximately 75.6 and $73.9 \mathrm{eV}$, corresponding to $\mathrm{Al}_{2} \mathrm{O}_{3}$ and $\mathrm{Al}(\mathrm{OH})_{3}$. For $\mathrm{Sn} 3 \mathrm{~d}$, there were two peaks in the $\mathrm{Sn} 3 \mathrm{~d}$ spectrum consistent with $\mathrm{Sn}$ $3 \mathrm{~d} 3 / 2$ at $494.9 \mathrm{eV}$ and $\mathrm{Sn} 3 \mathrm{~d} 5 / 2$ at $486.4 \mathrm{eV}$. This implies there was $\mathrm{SnO}_{2}$ in the corrosion products. Thus, the surface of the corrosion layer mainly consisted of a large amount of $\mathrm{Mg}(\mathrm{OH})_{2}, \mathrm{MgCO}_{3}$, and $\mathrm{MgCl}_{2} \cdot 6 \mathrm{H}_{2} \mathrm{O}$ and a little $\mathrm{Al}_{2} \mathrm{O}_{3}, \mathrm{Al}(\mathrm{OH})_{3}, \mathrm{ZnO}$, and $\mathrm{SnO}_{2}$.
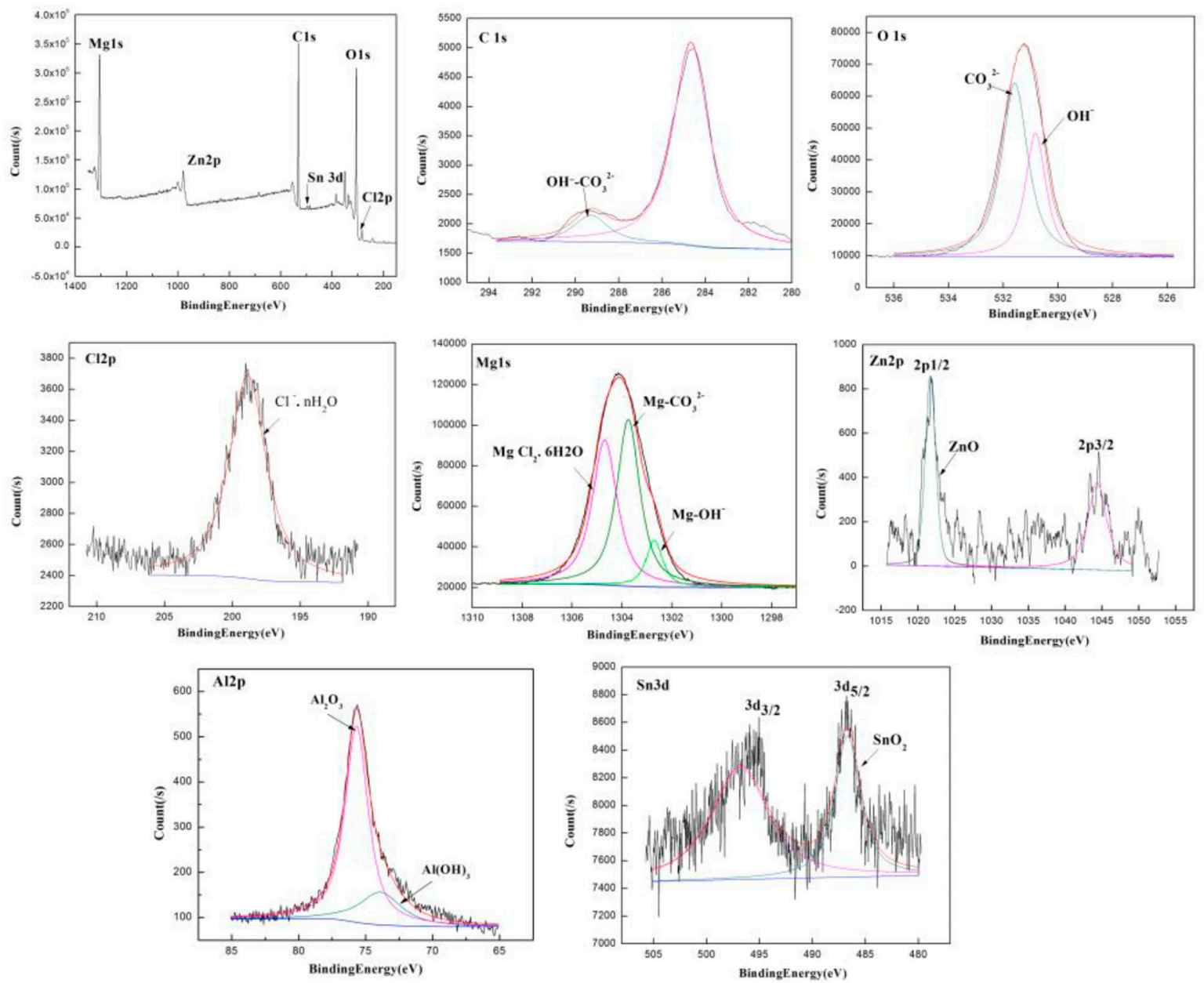

Figure 10. X-ray photoelectron spectroscopy (XPS) analysis results of ZAT543 alloy immersed in 3.5 wt $\% \mathrm{NaCl}$ for $48 \mathrm{~h}$.

From the corrosion behavior of the extruded alloys, the corrosion process can be divided into initiation, propagation, passivation, corrosion, and repassivation. At the initial stage of corrosion, severe microgalvanic corrosion occurred between the $\mathrm{Mg}_{2} \mathrm{Sn}$ and $\mathrm{Mg}$ matrix (Figure 8) on account of the stronger cathode effect and the potential difference with the matrix [41]. Pitting originated in the 
$\mathrm{Mg}_{2} \mathrm{Sn}$ phase. Meanwhile, the $\mathrm{Mg}$ matrix transferred to $\mathrm{Mg}^{2+}$ and $\mathrm{H}_{2} \mathrm{O}$ transferred to $\mathrm{OH}^{-}$, which was accompanied $\mathrm{H}_{2}$ release. Some $\mathrm{Mg}^{2+}$ combined with $\mathrm{OH}^{-}$to form $\mathrm{Mg}(\mathrm{OH})_{2}$. The reaction process can be described by Equation (1):

$$
\mathrm{Mg}+2 \mathrm{H}_{2} \mathrm{O}=\mathrm{Mg}(\mathrm{OH})_{2}+\mathrm{H}_{2} \uparrow .
$$

Therefore, the galvanic effect around $\mathrm{Mg}_{2} \mathrm{Sn}$ precipitation dominated in the initial corrosion stage, which accelerated alloy corrosion. From the $x$ E-PH diagram of the $\mathrm{Sn}-\mathrm{H}_{2} \mathrm{O}$ diagram [44], tin hydride formation reaction may have occurred by Equation (2):

$$
2 \mathrm{Mg}+\mathrm{Sn}+\mathrm{H}_{2} \mathrm{O}=\mathrm{SnH}_{4}+2 \mathrm{Mg}(\mathrm{OH})_{2}
$$

At this time, Sn adsorbed $\mathrm{H}$ atoms, reducing the rate of hydrogen evolution of alloys. With the reaction going on, Sn enriched on the surface of the alloy and the reaction occurred by Equation (3) [45]:

$$
\mathrm{SnH}_{4}+2 \mathrm{H}_{2} \mathrm{O}=\mathrm{SnO}_{2}+3 \mathrm{H}_{2} \uparrow .
$$

The corrosion products of $\mathrm{Mg}(\mathrm{OH})_{2}$ and $\mathrm{SnO}_{2}$ film (Figure 10) adhered to second phases, inhibiting the cathode effect of $\mathrm{Mg}_{2} \mathrm{Sn}$. With the continuous invasion of $\mathrm{Cl}^{-}, \mathrm{Mg}^{2+}$ combined with $\mathrm{Cl}^{-}$and $\mathrm{H}_{2} \mathrm{O}$ to form $\mathrm{MgCl}_{2} \cdot 6 \mathrm{H}_{2} \mathrm{O}$ corrosion products, which are soluble in aqueous solution. Meanwhile, more galvanic corrosion formed and the hydrogen evolution rate improved greatly due to the large number of $\mathrm{Mg}_{32}(\mathrm{Al}, \mathrm{Zn})_{49}$ phases in the alloys (Figure 3). Pitting corrosion transformed into filiform corrosion (Figure 9a) and further transformed to overall corrosion. The corrosion rate was inhibited due to the coverage of corrosion products such as $\mathrm{Mg}(\mathrm{OH})_{2}, \mathrm{MgCO}_{3}, \mathrm{Al}_{2} \mathrm{O}_{3}, \mathrm{Al}(\mathrm{OH})_{3}, \mathrm{ZnO}$, and $\mathrm{SnO}_{2}$ (Figures $9 \mathrm{~b}$ and 10 ) in the middle stage of corrosion. However, the protective film was porous, loose, and not compact, and $\mathrm{Cl}^{-}$could penetrate the film into the fresh alloys' surface and promote further acceleration of corrosion.

If the surface of the alloys can be repassivated, the corrosion resistance can be improved effectively. Soluble $\mathrm{Sn}$ and $\mathrm{Al}$ in the matrix deposit on the surface of the alloys, and a dense and stable oxide film $\left(\mathrm{Al}_{2} \mathrm{O}_{3}, \mathrm{SnO}_{2}\right)$ is formed. The stable passivation film protects the substrate from further corrosion $[32,46]$. However, the overall corrosion rate of the alloys depends on the quantity of precipitations. A large number of $\mathrm{Mg}_{2} \mathrm{Sn}$ in the extruded ZAT543 alloy increased pitting sites significantly and promoted the release rate of $\mathrm{H}_{2}$, accelerating matrix dissolution. The accelerated $\mathrm{H}_{2}$ evolution can undermine the passivation film, losing its protective effect [28].

The extruded ZAT541 alloy showed the best corrosion resistance. Due to nonobvious grain size changes, the influence on corrosion was not considered. The excellent corrosion resistance could be attributed to the following reasons. On the one hand, solutionized $\mathrm{Sn}$ in the $\mathrm{Mg}$ matrix reduced the rate of hydrogen evolution due to the high hydrogen overpotential, resulting in a low dissolution rate of the matrix. On the other hand, a large quantity of precipitations distributed uniformly on the matrix, resulting in the randomness and homogeneity of the galvanic corrosion.

\section{Conclusions}

The microstructure and corrosion behavior of extruded $\mathrm{Mg}-5 \mathrm{Zn}-4 \mathrm{Al}-\mathrm{xSn}$ alloys were studied. The main conclusions are as follows.

(1) The microstructure was different as more $\mathrm{Sn}$ was added. The as-extruded ZAT54x alloys consisted of $\alpha-\mathrm{Mg}, \mathrm{Mg}_{32}(\mathrm{Al}, \mathrm{Zn})_{49}$, and $\mathrm{Mg}_{2} \mathrm{Sn}$ phases. As the addition of $\mathrm{Sn}$ increased, grain refinement was achieved and the volume fraction of the $\mathrm{Mg}_{2} \mathrm{Sn}$ phase increased.

(2) The distribution of the second phases was uneven. They could act as cathodes to accelerate the corrosion of the matrix. $\mathrm{Mg}_{2} \mathrm{Sn}$ increased the possibility of pitting corrosion, the propagation of the corrosion rate, and the dissolution of the matrix. 
(3) Through potentiondynamic polarization curves, EIS, and immersion tests, the addition of Sn was better for improving the anticorrosion properties of $\mathrm{Mg}-\mathrm{Zn}-\mathrm{Al}$ alloys by solution strengthening. The extruded ZAT541 alloy exhibited optimal corrosion resistance, for which the $\mathrm{E}_{\text {corr }}$ and $\mathrm{I}_{\text {corr }}$ values were $-1.3309 \mathrm{~V}$ and $6.707 \times 10^{-6} \mathrm{~A} \cdot \mathrm{cm}^{-2}$, respectively.

Author Contributions: J.D., S.W., B.W., X.C., and F.P. designed the experiments; X.L., Y.L., X.X., and W.H. performed the experiments; X.L., B.W., and W.H. analyzed the data; X.L., B.W., and Y.W. wrote the paper; F.P. and B.X. provided theoretical direction.

Funding: The work was supported by the National Natural Science Foundation of China (Project Nos. 51675533, and 51701238), and the Equipment Pre-research Sharing Technology Project of the "13th five-year" (41404010205).

Conflicts of Interest: The authors declare no conflict of interests.

\section{References}

1. Bian, M.Z.; Sasaki, T.T.; Nakata, T.; Yoshida, Y.; Kawabe, N.; Kamado, S.; Hono, K. Bake-hardenable Mg-Al-Zn-Mn-Ca sheet alloy processed by twin-roll casting. Acta Mater. 2018, 158, 278-288. [CrossRef]

2. Hu, Y.B.; Zhang, C.; Meng, W.Q.; Pan, F.S.; Zhou, J.P. Microstructure, mechanical and corrosion properties of Mg-4Al-2Sn-xY-0.4Mn alloys. J. Alloys. Compd. 2017, 727, 491-500. [CrossRef]

3. Sugrib, K.S.; Hamid, J. Characterization of Nanolayer Intermetallics Formed in Cold Sprayed Al Powder on Mg Substrate. Materials 2019, 12, 1317.

4. Zhu, S.Q.; Yan, H.G.; Liao, X.Z.; Moody, S.J.; Sha, G.; Wu, Y.Z.; Ringer, S.P. Mechanisms for enhanced plasticity in magnesium alloys. Acta Mater. 2015, 82, 344-355. [CrossRef]

5. Hua, T.; Xiao, W.L.; Wang, F.; Li, Y.; Liu, S.Y.; Zheng, R.X.; Ma, C.L. Improving tensile properties of Mg-Sn-Zn magnesium alloy sheets using pretension and ageing treatment. J. Alloys. Compd. 2018, 735, 1494-1504. [CrossRef]

6. Yang, J.; Peng, J.; Nyberg, E.A.; Pan, F.S. Effect of Ca addition on the corrosion behavior of Mg-Al-Mn alloy. Appl. Surf. Sci. 2016, 369, 92-100. [CrossRef]

7. Liu, G.; Xie, W.; Wei, G.B.; Yang, Y.; Liu, J.W.; Xu, T.C.; Xie, W.D.; Peng, X.D. Dynamic Recrystallization Behavior and Corrosion Resistance of a Dual-Phase Mg-Li Alloy. Materials 2018, 11, 408. [CrossRef]

8. Mingo, B.; Arrabala, R.; Mohedano, M.; Mendis, C.L.; Olmo, R.D.; Matykina, E.; Hort, N.; Merino, M.C.; Pardo, A. Corrosion of Mg-9Al alloy with minor alloying elements (Mn, Nd, Ca, Y and Sn). Mater. Des. 2017, 130, 48-58. [CrossRef]

9. Nezamdoust, S.; Seifzadeh, D.; Rajabalizadeh, Z. PTMS/OH-MWCNT sol-gel nanocomposite for corrosion protection of magnesium alloy. Surf. Coat. Technol. 2018, 335, 228-240. [CrossRef]

10. Liu, W.; Yan, Z.J.; Ma, X.L.; Geng, T.; Wu, H.H.; Li, Z.Y. Mg-MOF-74/MgF 2 Composite Coating for Improving the Properties of Magnesium Alloy Implants: Hydrophilicity and Corrosion Resistance. Materials 2018, 11, 396. [CrossRef]

11. Tao, Y.S.; Xiong, T.Y.; Sun, C.; Jin, H.Z.; Du, H.; Li, T.F. Effect of a- $\mathrm{Al}_{2} \mathrm{O}_{3}$ on the properties of cold sprayed $\mathrm{Al} / \mathrm{a}-\mathrm{Al}_{2} \mathrm{O}_{3}$ composite coatings on AZ91D magnesium alloy. Appl. Surf. Sci. 2009, 256, 261-266. [CrossRef]

12. Zhong, Y.; Hu, J.; Zhang, Y.; Tang, Y. The one-step electroposition of superhydrophobic surface on AZ31 magnesium alloy and its time-dependence corrosion resistance in $\mathrm{NaCl}$ solution. Appl. Surf. Sci. 2018, 427, 1193-1201. [CrossRef]

13. Szklarz, Z.; Bisztyga, M.; Krawiec, H.; Lityńska-Dobrzyńska, L.; Rogal, Ł. Global and local investigations of the electrochemical behavior the T6 heat treated Mg-Zn-RE magnesium alloy thixo-cast. Appl. Surf. Sci. 2017, 405, 529-539. [CrossRef]

14. Jiang, J.; Yin, L.; Lu, F.; Ma, A.; Song, D.; Zhang, L.; Yang, D.; Chen, J. Microstructure and corrosion behaviour of Mg-2Gd-1Y-1Zn-0.2Zr (at.\%) alloy processed by equal channel angular pressing. Corros. Eng. Sci. Technol. 2014, 49, 316-320. [CrossRef]

15. Shi, Z.M.; Cao, F.Y.; Song, G.L.; Liu, M.; Atrens, A. Corrosion behaviour in salt spray and in $3.5 \% \mathrm{NaCl}$ solution saturated with $\mathrm{Mg}(\mathrm{OH})_{2}$ of as-cast and solution heat-treated binary $\mathrm{Mg}$ - $\mathrm{RE}$ alloys: $\mathrm{RE}=\mathrm{Ce}, \mathrm{La}, \mathrm{Nd}$, Y, Gd = Ce, La, Nd, Y, Gd. Corros. Sci. 2013, 76, 98-118. [CrossRef]

16. Meng, J.; Sun, W.; Tian, Z.; Qiu, X.; Zhang, D. 2-Corrosion performance of magnesium (Mg) alloys containing rare-earth (RE) elements. Corros. Prev. Magnes. Alloys 2013. [CrossRef] 
17. She, J.; Pan, F.S.; Hu, H. Microstructures and mechanical properties of as-extruded Mg-5Sn-1Zn-xAl ( $x=1,3$ and 5) alloys. Progre. Natuar. Sci. Mater. Inter. 2015, 25, 267-275. [CrossRef]

18. Kim, H.J.; Kim, B.; Baek, S.M.; Sohn, S.D.; Shin, H.J.; Jeong, H.Y.; Yim, C.D.; You, B.S.; Ha, H.Y.; Park, S.S. Influence of alloyed $\mathrm{Al}$ on the microstructure and corrosion properties of extruded $\mathrm{Mg}-8 \mathrm{Sn}-1 \mathrm{Zn}$ alloys. Corros. Sci. 2015, 95, 133-142. [CrossRef]

19. Nam, N.D.; Mathesh, M.; Le, T.V.; Nguyen, H.T. Corrosion behavior of Mg-5Al-xZn alloys in 3.5 wt. $\% \mathrm{NaCl}$ solution. J. Alloys Compd. 2014, 616, 662-668. [CrossRef]

20. Wang, J.F.; Li, Y.; Zhou, X.N. Study of the corrosion behavior and the corrosion films formed on the surfaces of Mg-xSn alloys in 3.5 wt.\% NaCl solution. Appl. Surf. Sci. 2014, 317, 1143-1150. [CrossRef]

21. Hou, L.D.; Li, Z.; Zhao, H.; Pan, Y.; Pavlinich, S.; Liu, X.W.; Li, X.L.; Zheng, Y.F.; Li, L. Microstructure, Mechanical Properties, Corrosion Behavior and Biocompatibility of As-Extruded Biodegradable Mg-3Sn-1Zn-0.5Mn. J. Mater. Sci. Technol. 2016, 32, 874-882. [CrossRef]

22. Wang, B.; Pan, F.S.; Chen, X.H.; Guo, W.; Mao, J.J. Microstructure and mechanical properties of as-extruded and as-aged Mg-Zn-Al-Sn alloys. Mater. Sci. Eng. A. 2016, 65, 165-173. [CrossRef]

23. Liu, C.Q.; Liu, C.L.; Chen, H.W.; Nie, J.F. Heat-treatable Mg-9Al-6Sn-3Zn extrusion alloy. J. Mater. Sci. Technol. 2018, 34, 284-290. [CrossRef]

24. Kim, B.; Lee, J.G.; Park, S.S. Superplasticity and load relaxation behavior of extruded Mg-8Sn-3Al-1Zn alloy at $250{ }^{\circ}$ C. Mater. Sci. Eng. A 2016, 656, 234-240. [CrossRef]

25. She, J.; Pan, F.S.; Zhang, J. Microstructure and mechanical properties of Mg-Al-Sn extruded alloys. J. Alloys. Compd. 2016, 657, 893-905. [CrossRef]

26. Wang, B.; Chen, X.H.; Pan, F.S.; Mao, J.J. Effects of Sn addition on microstructure and mechanical properties of Mg-Zn-Al alloys. Progre. Natuar. Sci. Mater. Inter. 2017, 27, 695-702. [CrossRef]

27. Zhu, S.Z.; Luo, T.J.; Yang, Y.S. Improving mechanical properties of age-hardenable Mg-6Zn-4Al-1Sn alloy processed by double-aging treatment. J. Mater. Sci. Technol. 2017, 33, 1249-1254. [CrossRef]

28. Jung, J.G.; Park, S.H.; You, B.S. Effect of aging prior to extrusion on the microstructure and mechanical properties of Mg-7Sn-1Al-1Zn alloy. J. Alloys. Compd. 2015, 627, 324-332. [CrossRef]

29. Shi, Z.Z.; Xu, J.Y.; Yu, J.; Liu, X.F. Microstructure and mechanical properties of as-cast and as-hot-rolled novel Mg-xSn-2.5Zn-2Al alloys (x=2, 4 wt\%). Mater. Sci. Eng. A 2018, 712, 65-72. [CrossRef]

30. Park, S.H.; You, B.S. Effect of homogenization temperature on the microstructure and mechanical properties of extruded Mg-7Sn-1Al-1Zn alloy. J. Alloy. Compd. 2015, 637, 332-338. [CrossRef]

31. Metalnikov, P.; Hamu, G.B.; Eliezer, D.; Shin, K.S. Role of Sn in microstructure and corrosion behavior of new wrought Mg-5Al alloy. J. Alloys. Compd. 2019, 777, 835-849. [CrossRef]

32. Cain, T.W.; Glover, C.F.; Scully, J.R. The corrosion of solid solution Mg-Sn binary alloys in NaCl solutions. Electrochim. Acta 2019, 297, 564-575. [CrossRef]

33. Ha, H.Y.; Kang, J.Y.; Yang, J.; Yim, C.D.; You, B.S. Role of Sn in corrosion and passive behavior of extruded Mg-5 wt\% Sn alloy. Corros. Sci. 2016, 102, 355-362.

34. Boby, A.; Srinivasan, A.; Pillai, U.S.; Pai, B.C. Mechanical characterization and corrosion behavior of newly designed Sn and Y added AZ91 alloy. Mater. Des. 2015, 88, 871-879.

35. Humphreys, F.J.; Hatherly, M. Recrystallization and Related Annealing Phenomena, 2nd ed.; Elsevier: Oxford, UK, 2004; pp. 285-292.

36. Lin, H.Q.; Wang, J.G.; Wang, H.Y.; Jiang, Q.C. Effect of predeformation on the globular grains in AZ91D alloy during strain induced melt activation (SIMA) process. J. Alloy. Compd. 2007, 431, 141-147. [CrossRef]

37. Kim, K.; Yoon, J. Effects of starting microstructure and billet orientations on the texture evolution and the mechanical behavior of Mg-3Al-1Zn rolled plate by half channel angular extrusion (HCAE). Mater. Sci. Eng. A 2015, 622, 46-51. [CrossRef]

38. Song, Y.W.; Han, E.H.; Shan, D.Y.; Yim, C.D.; You, B.S. The effect of Zn concentration on the corrosion behavior of Mg-xZn alloys. Corros. Sci. 2012, 65, 322-330. [CrossRef]

39. Curioni, M. The behaviour of magnesium during free corrosion and potentiodynamic polarization investigated by real-time hydrogen measurement and optical imaging. Electrochim. Acta. 2014, 120, 284-292. [CrossRef]

40. Rajabalizadeh, Z.; Seifzadeh, D. Application of electroless Ni-P coating on magnesium alloy via CrO3/HF free titanate pretreatment. Appl. Surf. Sci. 2017, 422, 696-709. [CrossRef] 
41. Ha, H.Y.; Kang, J.Y.; Kim, S.G.; Kim, B.; Park, S.S.; Yim, C.D.; You, B.S. Influences of metallurgical factors on the corrosion behaviour of extruded binary Mg-Sn alloys. Corros. Sci. 2014, 82, 369-379. [CrossRef]

42. Gheshlaghi, M.G.; Seifzadeh, D.; Shoghi, P.; Yangjeh, A.H. Electroless Ni-P/nano-WO3 coating and its mechanical and corrosion protection properties. J. Alloys. Compd. 2018, 769, 149-160. [CrossRef]

43. Feng, H.; Liu, S.H.; Du, Y.; Lei, T.; Zeng, R.C.; Yuan, T.C. Effect of the second phases on corrosion behavior of the Mg-Al-Zn alloys. J. Alloys. Compd. 2017, 695, 2330-2338. [CrossRef]

44. Bai, X. Chemistry of Nuclear Materials; Press of Chemical Industry: Beijng, China, 2007.

45. Liu, X.B.; Shan, D.Y.; Song, Y.W.; Chen, R.S.; Han, E.N. Influences of the quantity of $\mathrm{Mg}_{2} \mathrm{Sn}$ phase on the corrosion behavior of Mg-7Sn magnesium alloy. Electrochim. Acta 2011, 56, 2582-2590. [CrossRef]

46. Zhong, L.P.; Wang, Y.J.; Lu, H.; Cui, X.J.; Zhang, Y.J.; Dou, B.J.; Peng, J. Influence of aging prior to extrusion on the microstructure and corrosion resistance of Mg-8Sn-2Zn-0.2Mn alloy. J. Alloy. Compd. 2019, 780, 783-791. [CrossRef]

(C) 2019 by the authors. Licensee MDPI, Basel, Switzerland. This article is an open access article distributed under the terms and conditions of the Creative Commons Attribution (CC BY) license (http://creativecommons.org/licenses/by/4.0/). 